\title{
The Strategy of Enterprise Financial Accounting Innovation under Internet development
}

\author{
Wen Tian \\ School of Nanjing University of Science and Technology, Nanjing 210014, China \\ tianwen31415@vip.qq.com
}

Keywords: Internet development, corporate financial accounting, innovation strategy.

\begin{abstract}
In recent years, with the continuous development of information technology, the "Internet +" era came into being. In this context, market competition is gradually fierce, and the pressure on enterprises is gradually increasing. Corporate financial accounting is not only directly related to the development of the enterprise, but its level will also have a certain impact on the economic benefits of the enterprise. However, under the background of Internet development, the traditional financial accounting work method can no longer meet the needs of today's social development. Therefore, how to innovate the financial accounting work of enterprises has become particularly important.
\end{abstract}

\section{Introduction}

With the continuous development of our society, all walks of life have witnessed a booming trend. Under the background of Internet development, applying existing network information technology to corporate work can effectively improve the efficiency of enterprise work. At the same time, it will bring considerable economic benefits to the company. Financial accounting work is an indispensable part of the development process of the enterprise. Its level will directly affect the accuracy of the financial management information of the enterprise. This article will examine how to innovate existing financial accounting efforts.

\section{The change of enterprise financial accounting}

\subsection{Changes in accounting mode}

With the advent of the Internet era, it has created opportunities for the development of all walks of life in China. As an important participant in China's social economy, the internal financial accounting work has also ushered in greater change and development. [1] Under the Internet perspective, corporate financial accounting work pays more attention to accounting work and supervision. This is a direct reflection of corporate financial accounting's emphasis on its own analysis and control functions. The rational application of advanced technology requires changing the traditional way of 
working, and using computer technology and database management technology to calculate and calculate the fixed capital and standard capital of the enterprise to ensure its feasibility, so as to quantitative analysis for subsequent enterprises. Strategic decision-making provides the basis.

\subsection{Changes in the accounting process}

From the perspective of traditional corporate financial accounting, business process and accounting accounting exist as two separate individuals in financial accounting, and both departments have relevant responsible personnel to be responsible for work management. Under the "Internet + " perspective, corporate financial accounting has effectively integrated business processes with accounting accounting. From the perspective of the enterprise as a whole, the operation of the enterprise is unified and integrated, and the upstream and downstream management of the enterprise In the process, there will be very large data information, and corporate financial accounting work is an important part of the internal management of the enterprise, so this background should fully play its role. After the entire business process is clear, the enterprise financial accountant uses the existing network technology to integrate and analyze the relevant data, thus providing accurate and effective data for the enterprise, laying a good foundation for the enterprise's later development decision-making and management.

\section{Problems faced by corporate financial accounting}

From the perspective of Internet development, we can find that there are still some problems in the current financial accounting work. First of all, the existing financial accounting management methods and concepts can no longer adapt to the development of today's society. Enterprises lack certain rationality in the allocation of financial accounting power. For example, some enterprises have greater rights to allocate financial accounting, which will result in the head office being unable to the accounting department controls the risks in the production and operation of the enterprise. When some enterprises assign rights to financial accounting, their rights are small, so the management rights of the head office will increase accordingly, which will lead to the lack of rights of the subordinate companies, which will lead to the decrease of employees' enthusiasm for work and low enthusiasm. Secondly, at present Internet information technology has been widely used in all walks of life in China. Although most enterprises have a deeper understanding of information technology, in the specific implementation process, the effect is not satisfactory, and the level of enterprise informationization cannot be effectively improved.

\section{Corporate financial accounting innovation strategy}

\subsection{Innovate existing work concepts}

In order to meet the needs of social development, financial accounting innovation is imperative. In order to better promote the development of enterprises, corporate financial accounting personnel should timely change their own ideas, based on social development trends and actual needs, timely update relevant data in the work process, and relevant corporate leaders should also give this with a high degree of attention, improve the strategic height of corporate financial accounting innovation in enterprise development. [2] Increase capital investment in corporate financial accounting, provide necessary financial support for financial accounting reform and innovation, and conduct in-depth research on the development of financial accounting work under the Internet environment, analyze its characteristics, and lay the foundation for subsequent innovation work. Good foundation. In addition, 
Internet development also provides a certain development direction for financial accounting innovation. Therefore, in the process of innovation, enterprises should fully integrate their own actual conditions and take the Internet development era as the guide, and promote innovation work. Standardization. It is worth mentioning that enterprises should attach great importance to the distribution of financial accounting rights of enterprises, ensure the scientific and rational distribution, and thus ensure the smooth completion of innovation work.

\subsection{Improve various facilities}

The improvement of financial accounting facilities is the key to ensuring its innovation. Generally speaking, it mainly includes hardware facilities and software facilities. From the perspective of hardware facilities, enterprises should provide complete information equipment for the financial accounting department, and guide staff to use information equipment to carry out part of the work, thus ensuring the informationization of financial accounting and effectively improving its work efficiency. For example, enterprises can configure intelligent terminals to help complete information collection and sharing in the process of financial accounting. From the perspective of software, it is necessary to make reasonable selection and configuration of the staff of the financial and accounting department of the enterprise according to the actual situation of the enterprise, so as to better meet the needs of financial accounting innovation of the enterprise.

\subsection{Focus on the cultivation and introduction of professional talents}

The construction of professional talent team is a necessary condition for the innovation of corporate financial accounting. At present, the quality of talents in the financial and accounting departments of enterprises is relatively low, and the lack of high-quality professionals is the main reason that hinders financial accounting innovation. [3] Therefore, in the process of innovating corporate financial accounting, enterprise management personnel should regularly train existing financial accounting personnel according to their actual conditions and personnel conditions to improve the overall quality level of corporate financial personnel, in the later financial aspects. When problems are encountered, they can be solved with high efficiency, so that work efficiency can be effectively improved. At the same time, it is also possible to introduce outstanding professional talents from outside, so that the advanced financial accounting experience and methods of the outside world can enter the enterprise, so that the existing staff of the enterprise can learn more advanced knowledge and work experience, so as to better apply it. In the course of work, a high-quality financial accounting talent with strong professional ability is established to increase the competitiveness of enterprises in the industry.

\section{Security construction of computer systems}

There are confidentiality characteristics in financial accounting data. In order to solve the problems arising during the period, it is necessary to change the financial accounting work system of the enterprise. During the implementation of specific work, it is necessary to promote the perfection of the division of labor and management system, divide the duties and positions of financial accounting staff, and achieve a sound financial accounting system. During the work period, financial accountants are required to keep the personal account password confidential to prevent the password from leaking. It is also necessary to realize the authorization management system of user rights and responsibilities, and clearly define the responsibilities of financial accounting posts to ensure that the responsibilities of each position can be divided within a reasonable range. Not only that, but also the 
internal control work needs to promote the perfection and security of the establishment of computer network systems, in which three aspects need to be improved during the execution of the work. [4] First, strengthen the firewall, use virus killing and isolation technology, and implement access rights to some key documents to ensure the normal and stable operation of the accounting system. Second, it is necessary to implement regular updates, maintenance work, etc., to promote the completion of the financial accounting operating system, in order to maintain the security and integrity of the financial accounting network. Third, to promote the effective design of network systems, for the loopholes generated in the financial accounting network system, to use the relevant software backup. At the same time, financial accountants need to recognize some problems arising from the use of software during the use of some software, whether in terms of settlement, accounting, etc., they need to be accounted for. In this work, not only can some errors be reduced, but also a steady increase in work efficiency can be promoted.

\section{Summary}

In summary, under the Internet development, corporate financial accounting innovation is particularly necessary, and is of key significance to promote the steady development of enterprises. At present, there are still some shortcomings in corporate financial accounting. Therefore, if enterprises want to meet the needs of social development and improve their own competitiveness, they must closely integrate advanced network information technology with their actual conditions, continuously innovate their work concepts, and improve financial accounting. The hardware facilities and software facilities at work lay a good foundation for the innovation of financial accounting. In addition, we must pay attention to the cultivation and introduction of talents, and build a professional team of high-quality talents, so as to effectively improve the competitiveness of enterprises.

\section{References}

[1] Xuzhang Wang, Jinjia Tan. Enterprise Financial Accounting Innovation under the Background of "Internet +"[J].Tax magazine, 2018(11):182.

[2] Lei Ju. Research on the Practice of Enterprise Financial Accounting Innovation Based on the Background of "Internet+"[J].Tax magazine, 2018(13):148-149.

[3] Tianhang Liu. The Practice of Enterprise Financial Accounting Innovation under the Background of "Internet +"[J].Tax magazine, 2018(12):205.

[4] Zhu Wang. Research on Problems and Countermeasures of Financial Accounting Management in the Age of Network Economy [J].China Business \& Trade, 2015(4):33-34 